\title{
Heat fluxes of the Indian Ocean from a global eddy-resolving model
}

\author{
U. Garternicht and F. Schott \\ Institut für Meereskunde an der Universität Kiel, Kiel, Germany
}

\begin{abstract}
The output of the global eddy-resolving $1 / 4^{\circ}$ ocean model of Semtner/Chervin (run by the Naval Postgraduate School, Monterey, California) has been used to study the oceanic temperature and heat flux in the Indian Ocean. The meridional heat flux in the northern Indian Ocean is at the low end of the observed values. A vertical overturning cell in the upper $500 \mathrm{~m}$ is the main contributor to the annual mean meridional heat flux across $5^{\circ} \mathrm{S}$, whereas the horizontal gyre circulation, confined to the upper $500 \mathrm{~m}$, dominates north of the equator. The change of monsoon winds is manifested in a reversal of the meridional circulation throughout the whole water column. The most notable result is a strong linear relationship of the meridional temperature flux and the zonal wind stress component north of $20^{\circ} \mathrm{S}$. The model's Pacific-Indian Ocean throughflow across the section at $120^{\circ} \mathrm{E}$ accounts for $-8.8 \pm 5.1 \mathrm{~Sv}\left(1 \mathrm{~Sv} \equiv 10^{6} \mathrm{~m}^{3} \mathrm{~s}^{-1}\right)$. A strong interannual variability during the model run of 3 years shows a maximum range of $12 \mathrm{~Sv}$ in January/February and a minimum during March through June. The inflow from the Pacific into the Indian Ocean results in a total annual mean temperature flux of $-0.9 \mathrm{PW}\left(1 \mathrm{PW} \equiv 10^{15} \mathrm{~W}\right)$. In the model the temperature flux from the Pacific through the Indian Ocean to the south dominates in comparison with the input of solar heat from the northern Indian Ocean.
\end{abstract}

\section{Introduction}

The different solar heating at the poles and the equator requires a meridional heat flux from low to high latitudes to maintain a steady state in which the local mean temperature remains constant. In that way the variability of the meridional heat flux and the radiation budget are fundamental to the Earth's climate. Although earlier works attribute the major contribution to the meridional heat flux to the atmosphere [Bjerknes et al., 1933; Sverdrup et al., 1942], more recent papers [Carissimo et al., 1985; Trenberth and Solomon, 1994] indicate that in the global mean the transport occurs in about equal parts through the atmosphere and the oceans.

The importance for the Earth's climate has served as one motivation for developing several different methods to calculate the oceanic heat flux. Bryden and Hall [1980] described a method for meridional heat flux estimation, which uses observational data of one transoceanic hydrographic section, direct measurements in the western boundary current, and a wind stress climatology for the Ekman transport to calculate the different components of the meridional heat flux. They made use of the fact that the vertically integrated potential temperature is nearly constant along a zonal transoceanic section, making the heat transport independent of where the barotropic return flow of the western boundary

\section{Copyright 1997 by the American Geophysical Union.}

Paper number 97JC01585.

0148-0227/97/97JC-01585\$09.00 current occurs. It thus eludes the classical problem of the unknown reference velocity. Another way to deal with that problem is the inverse method, which has been introduced to oceanographic transport calculations by Wunsch [1977].

Besides these "oceanographic" methods there is another group of "atmospheric" methods, which compute the mean oceanic heat flux divergence as the residual of the sea surface flux. For seasonal analysis the oceanic heat content change has to be taken into consideration too. Meridional integration of the sea surface flux divergence and the oceanic heat content change between lateral boundaries yields the meridional heat flux for individual ocean basins. Hsiung et al. [1989] estimated sea surface fluxes from bulk formulas, using climatological data for all three oceans; Hastenrath and Greischar [1993] did this calculation for the Indian Ocean. A second meteorological method is to calculate the oceanic heat transport as the residual from the atmospheric heat transport divergence and the radiation budget at the top of the atmosphere, as was first demonstrated by Carissimo et al. [1985]. In a recent application of that method, Trenberth and Solomon [1994] calculated the oceanic heat flux by combining top-of-the-atmosphere radiation data from the Earth $\mathrm{Ra}$ diation Budget Experiment (ERBE) of the year 1988 with European Centre for Medium-Range Weather Forecasts (ECMWF) atmospheric data.

Although all of these methods have gained further sophistication since they were introduced, there still remain significant uncertainties. Ocean general circulation models (OGCMs) offer another independent opportunity to estimate the oceanic heat flux. Bryan and Lewis [1979] were the 
first to calculate the meridional oceanic heat flux from an OGCM and to determine the role of the meridional overturning process involved with it. Since then a number of increasingly realistic numerical models, both basin and global scale, have been applied to yield heat flux estimates. Most of the model analyses have focused on the North Atlantic Ocean [e.g., Sarmiento, 1986; Böning and Herrmann, 1994]; some have focused on the global scale [e.g., Semtner and Chervin, 1992; Covey, 1995]. Only recently has the focus turned to the Indian Ocean. Wacongne and Pacanowski [1996] determined the annual cycle and the mechanisms of the meridional heat flux from a tropical Indian Ocean primitive equation model. The annual mean heat flux in the Indian Ocean was investigated by Lee and Marotzke [1997], using the adjoint of an OGCM.

The present study investigates the oceanic heat flux in the Indian Ocean from the output of a global eddy-resolving ocean circulation model with a mean grid spacing of $1 / 4^{\circ}$, which is an advanced version of the model of Semtner and Chervin [1988, 1992]. In the next section there is a brief description of the model output and the methods used for this computation. The following three sections deal with the answer to these questions: Does the model's heat flux resemble the values obtained by other methods? How does the variation of the monsoon winds alter the meridional heat flux, and what is the mechanism of heat flux in the model? How does the Pacific-Indian Ocean throughflow influence the Indian Ocean? The last section gives a summary together with a discussion of some of these topics.

\section{Model and Data Analysis}

The calculations are based on the data output of a global eddy-resolving ocean model (Parallel Ocean Climate Model) provided courtesy of A. J. Semtner (Naval Postgraduate School, Monterey, California). The model is a further development of the model described by Semtner and Chervin [1988, 1992]. It is sometimes called the Bryan-Cox-Semtner ocean model to describe the development from its origin published by Bryan [1969] and Cox [1975]. It is a threedimensional primitive equation ocean model on a Mercator grid with a mean grid spacing of $1 / 4^{\circ}$. The integration over a period of 5 years uses the output of preceding model runs with $1 / 2^{\circ}$ grid spacing covering 33 years. Monthly mean values of the horizontal velocity components, salinity and potential temperature from the last 3 years of the integration, representing the period 1987-1989, were used in this analysis. For the Indian Ocean area selected (see Figure 1) there is an effective grid spacing of about $0.4^{\circ}$. The model is capable of resolving mesoscale eddies because of the dense grid point coverage and the application of a scale-dependent horizontal biharmonic friction term. The thickness of the 20 vertical layers varies from $25 \mathrm{~m}$ near the surface up to $550 \mathrm{~m}$ at depth, where the deepest layer reaches down to $5200 \mathrm{~m}$. The surface layer was driven by monthly mean values of wind stress analyzed by the ECMWF covering the period 1987-1989. At the surface a relaxation with a timescale of 1 month forces temperature and salinity to climatological values [Levitus, 1982], simulating the sea surface fluxes of energy and fresh water. A further relaxation occurs at the borders of the model, south of $65^{\circ} \mathrm{S}$ and north of $55^{\circ} \mathrm{N}$, as well as at the Straits of Gibraltar in the Atlantic. Below the main thermocline, temperature and salinity were prognostic. This situation differs from preceding model versions, in which relaxation to climatology has been applied at depth greater than $700 \mathrm{~m}$.

Figure 2 gives an example of the qualitatively good performance of the model, here depicted for the surface circulation. Monthly mean values of the surface velocity are shown for January 1989 (Figure 2a) and July 1989 (Figure $2 \mathrm{~b}$ ) to illustrate the tremendous changes of the current structure from the NE to the SW monsoon. Large-scale features such as the year-round South Equatorial Current (SEC), the reversing Northeast/Southwest Monsoon Current (NMC/SMC) south of Sri Lanka [e.g., Schott et al., 1994], the reversal of the Somali Current (SC), and the South Equatorial Countercurrent (SECC) are present in the model. The development of the two-gyre system off Somali during the SW monsoon [e.g., Schott, 1983] seems to be represented in the model; it consists of the Southern Gyre (SG) near the equator and the Great Whirl (GW) north of it. On the other hand, the gyre south of the equator at the western boundary during the NE monsoon is not supported by observations [e.g., Swallow et al., 1991].

Temperature flux $Q_{0}$ as used in this paper is defined as the integral throughout the whole water column,

$$
Q_{\mathrm{o}}=c_{p} \rho \iint \theta_{c} v d x d z
$$

where $c_{p}$ is the specific heat of sea water at constant pressure, $\rho$ is the density of sea water, $\theta_{c}$ is the potential temperature in degrees Celsius, $v$ is the across-section velocity component, $x$ is the direction along the section, and $z$ is the vertical direction. Here, $c_{p} \rho$ was taken to be the constant

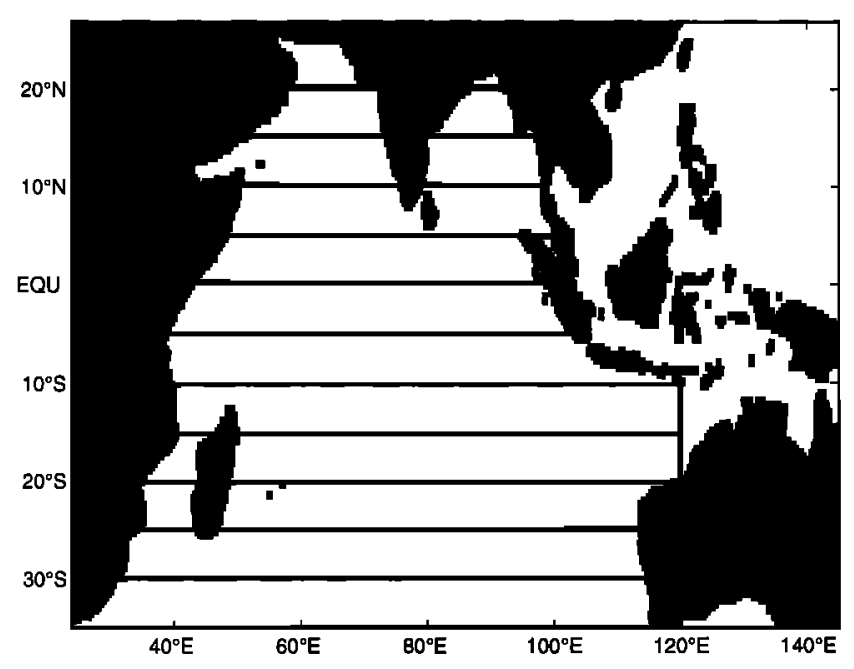

Figure 1. Map of the Indian Ocean in the model. The lines indicate the sections across which the fluxes have been calculated. Note that the Sunda Strait between Java and Sumatra (at $105^{\circ} \mathrm{E}, 6^{\circ} \mathrm{S}$ ) is open in the model. 

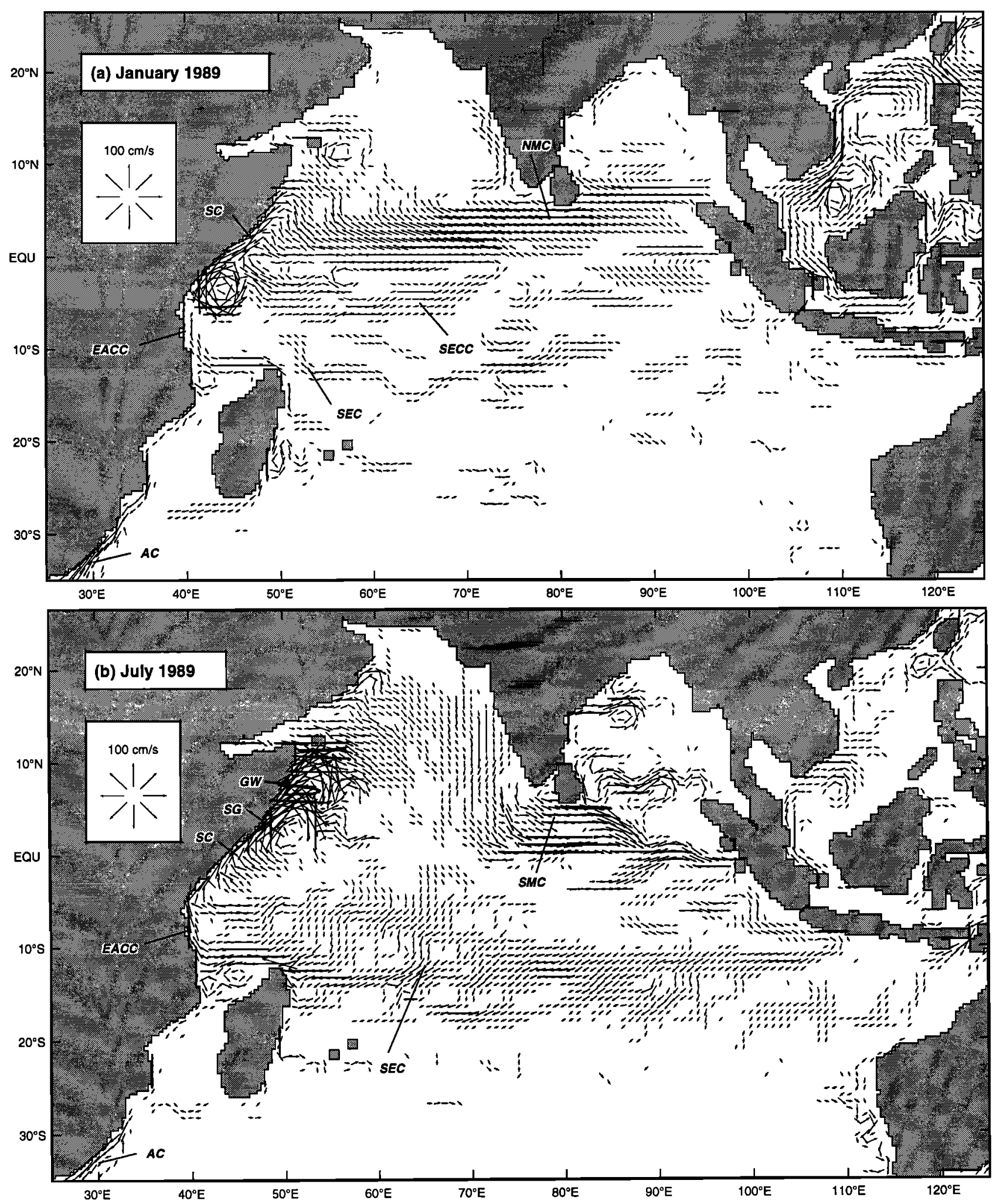

Figure 2. Monthly mean surface currents of the model during (a) NE monsoon (January 1989) and (b) SW monsoon (July 1989). Currents less than $20 \mathrm{~cm} / \mathrm{s}$ have been omitted. Additionally, only each second value is shown. The abbreviations are explained in the text.

value $4 \times 10^{6} \mathrm{~J} \mathrm{~kg}^{-1} \mathrm{~K}^{-1}$, since $c_{p}(S, T, p=0)$ is about or even less than $4000 \mathrm{~J} \mathrm{~kg}^{-1} \mathrm{~K}^{-1}$ in most places of the ocean and $\rho$ is slightly above $1000 \mathrm{~kg} \mathrm{~m}^{-3}$. To calculate the meridional temperature flux, a basin-wide integration was conducted along the sections shown in Figure 1. Positive values indicate northward or eastward fluxes depending on the orientation of the section. In the model, diffusive temperature fluxes are small in comparison with advective temper- 
ature fluxes, as McCann et al. [1994] show for the preceding model version.

It is important to bear in mind that the temperature flux defined this way is not equal to the heat flux, i.e., the effective transported energy. Only in the case of zero net volume flux through the section of integration is this value equal to the total amount of energy transported through this section [Bryan, 1962]. Zonal sections across the closed basin north of $5^{\circ} \mathrm{S}$ have nearly zero mean volume flux on a monthly basis. The zonal sections south of this latitude and the meridional section in the Indonesian passage at $120^{\circ} \mathrm{E}$ have a net volume flux due to the lateral inflow from the Pacific (Figure 1).

The Pacific-Indian Ocean throughflow would only allow presenting the stream function of the meridional volume transport for the sector north of the Indonesian passage. To offer an approximate stream function for the southern sector, the Pacific-Indian Ocean throughflow has been subtracted south of $10^{\circ} \mathrm{S}$ to obtain a nondivergent transport field. It is assumed that the lateral inflow spreads along the model layers with no net exchange between the layers. In the following it has to be kept in mind that the stream function is not exact south of $10^{\circ} \mathrm{S}$.

A common, although formal, decomposition is to divide the circulation into a horizontal gyre component and a vertical overturning component [e.g., Bryan and Lewis, 1979]. The heat flux per unit depth of the horizontal cell $Q_{\mathrm{h}}$ is given as

$$
Q_{\mathbf{h}}(z)=c_{p} \rho \int_{L(z)}(v-\langle v\rangle)(\theta-\langle\theta\rangle) d x
$$

where $L(z)$ is the width of the section in a depth $z$ and angle brackets denote mean values of properties along the section at depth $z$. With the use of this definition the volume flux of the horizontal cell is exactly zero at any depth; hence the integral describes the transported energy per unit depth of the horizontal cell. The heat flux of the overturning cell $Q_{v}$ is given as

$$
Q_{\mathrm{v}}=Q_{\mathrm{o}}-Q_{\mathrm{h}}=c_{p} \rho \int\langle v\rangle\langle\theta\rangle L(z) d z
$$

The integration takes place over depth ranges with no net volume flux to obtain the effective transported energy.

The Ekman contribution to the meridional temperature flux $Q_{\text {ekm }}$ is defined here by the basin-wide integral

$$
Q_{\text {ekm }}=-\int \frac{\tau^{(x)}}{f} c_{p}\left(\theta_{\text {surf }}-\bar{\theta}\right) d x
$$

where $\tau^{(x)}$ is the zonal mean of the zonal wind stress component, $f$ is the Coriolis parameter, $\theta_{\text {surf }}$ is the potential temperature of the model's surface layer $(0-25 \mathrm{~m}), \bar{\theta}$ is the average temperature of the section, and $x$ is the eastward direction. The wind stress was taken from the ECMWF analysis for the years 1987-1989. The integral has been computed for every single month of these years and was averaged afterward. This definition assumes that the Ekman transport is compensated by a barotropic current at section mean temperature.

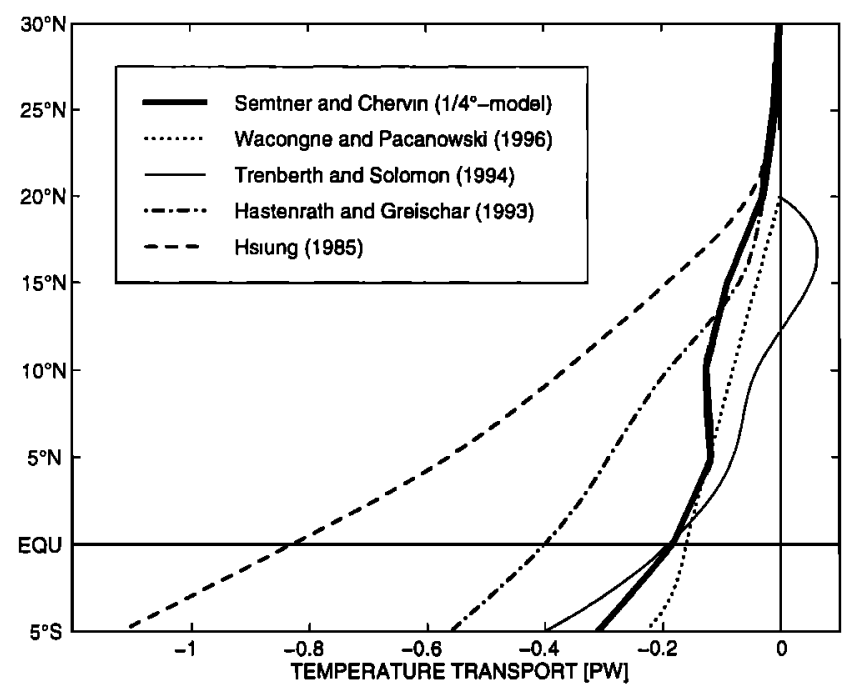

Figure 3. Annual mean meridional heat flux in the model (1987-1989) compared with values obtained from climatological data used in bulk formulas by Hastenrath and Greischar [1993] and Hsiung [1985]. Trenberth and Solomon [1994] used top-of-the-atmosphere radiation data of the year 1988 together with atmospheric data from the ECMWF model. The curve of Wacongne and Pacanowski [1996] is from a primitive equation model of the Indian Ocean. Negative values indicate heat flux to the south.

\section{Meridional Heat Flux in the Northern Indian Ocean}

The annual mean meridional heat flux of the Indian Ocean north of $5^{\circ} \mathrm{S}$ is shown in Figure 3. Model results are compared to those of Hastenrath and Greischar [1993] and Hsiung [1985], who used climatological data from marine observations and bulk formulas in their analysis. Trenberth and Solomon [1994] used atmospheric data of the year 1988 for their calculations. Heat fluxes from a Geophysical Fluid Dynamics Laboratory (GFDL) model implementation for the Indian Ocean are investigated by Wacongne and Pacanowski [1996]. The model's meridional heat flux is at the lower end of the published values, with the lowest cross-equatorial heat flux of -0.18 PW. The results of Wacongne and Pacanowsk [1996] and Trenberth and Solomon [1994] show good agreement with the model's heat flux near the equator, but Trenberth and Solomon [1994] found an unusual northward heat flux at $10^{\circ}-20^{\circ} \mathrm{N}$. The model's southward heat flux decreases slightly at $5^{\circ} \mathrm{N}$, an occurrence that seems unrealistic in comparison with the estimates of all other methods.

During the year the heat flux changes its sign by transporting heat to the winter hemisphere. Figure 4 shows the latitudinal distribution of the annual cycle of the heat flux for the northern Indian Ocean in the model (Figure 4a) in comparison with the results of Hastenrath and Greischar [1993] (b) and in comparison with the results of Hsiung et al. [1989] (c). All distributions show a prevailing annual harmonic. The agreement in magnitude and phase is very good in the north and decreases to the south. Between April/May and October/November the model transports heat to the south in the whole northern Indian Ocean nearly independently of 

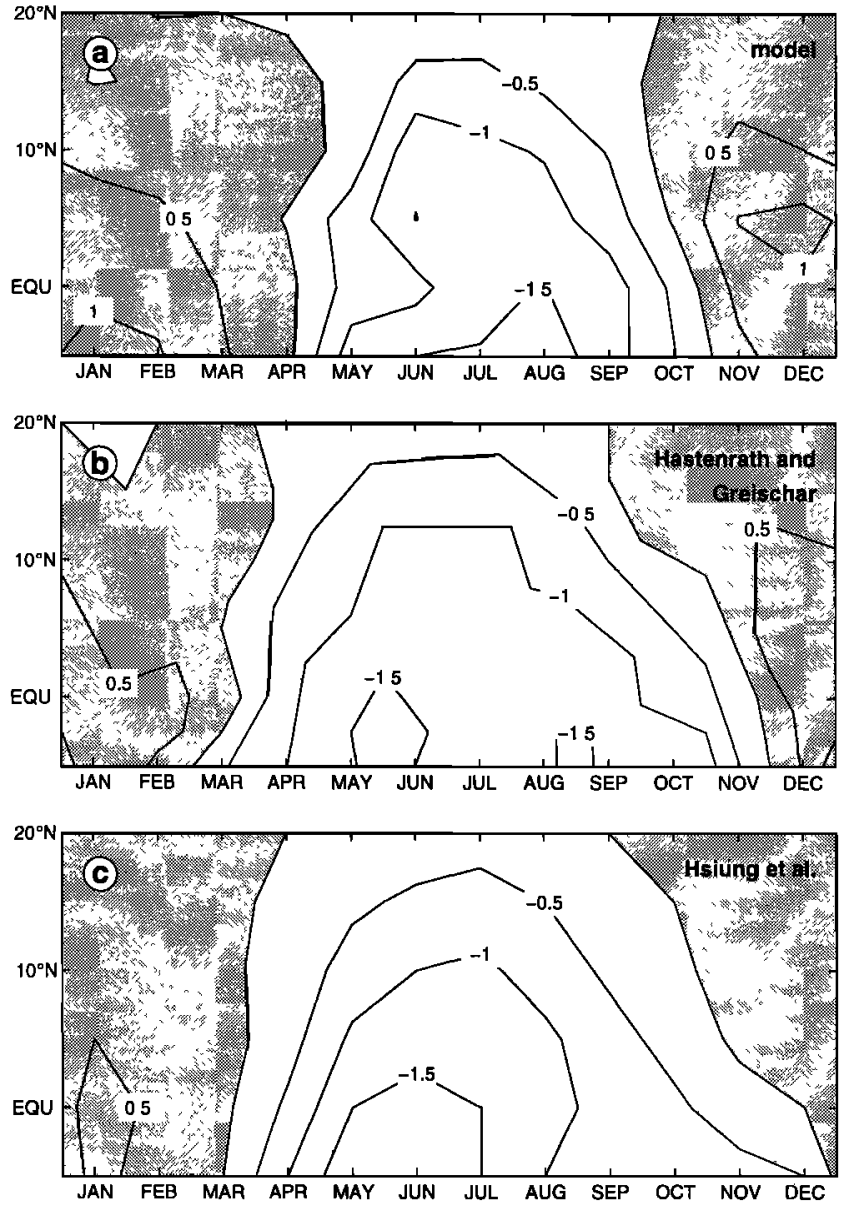

Figure 4. Mean annual cycle of meridional heat flux (a) in the model (1987-1989), (b) from climatological data after Hastenrath and Greischar [1993], and (c) after Hsiung et al. [1989]. Values are given in PW. Shaded areas indicate positive values, i.e., northward heat flux.

latitude. In contrast, climatological values show an increasing length of the period of southward heat flux toward lower latitudes, which at $5^{\circ} \mathrm{S}$ covers almost three fourths of the year and lasts from March through November/December. In a general agreement the maximum of southward heat flux takes place in June/July in the north. In the model the maximum at the equator appears in August, 3 months later than it does in the results of Hsiung et al. [1989]. As a unique feature, Hastenrath and Greischar [1993] found two local maxima of southward heat flux near the equator in May/June and August/September. The difference between the two climatologies of Hastenrath and Greischar [1993] and Hsiung et al. [1989] arises from the partly differing data sets of marine surface observations (subsurface data are the same in both studies) and the different data processing. While Hastenrath and Greischar [1993] take the transfer coefficient in the bulk formulas to be constant, it is a function of wind speed and atmospheric stability in the work of Hsiung et al. [1989].

Overall the annual mean model heat flux to the south is less intense at low latitudes in comparison with climatological values for at least two reasons. First, the magnitude of southward heat flux is similar in all three pictures, but at low latitudes the length of the period of southward heat flux is longer in the climatological results than in the model. Second, the northward heat flux in boreal winter is stronger in the model than in the climatological results.

\section{Mechanism of the Meridional Temperature Flux in the Northern Indian Ocean}

The ocean is driven by two mechanisms, thermohaline convection and wind stress acting on the sea surface. Here we investigate the role of the wind stress in causing model heat flux variability. Figure 5 shows the correlation of the meridional temperature flux and the zonal mean of the zonal wind stress component. Each data point represents 1 month of the years 1987-1989. A linear regression analysis has been performed separately at each zonal section. Examples are shown together with the standard deviation of the distance of the data points in the $y$ direction from the fitted line for the latitudes $10^{\circ} \mathrm{N}, 10^{\circ} \mathrm{S}$, and $30^{\circ} \mathrm{S}$. The different symbols used for single years indicate no uniform trend of an anomalous zonal wind stress component in a single year. One exception is the South Indian Ocean at $30^{\circ} \mathrm{S}$, where
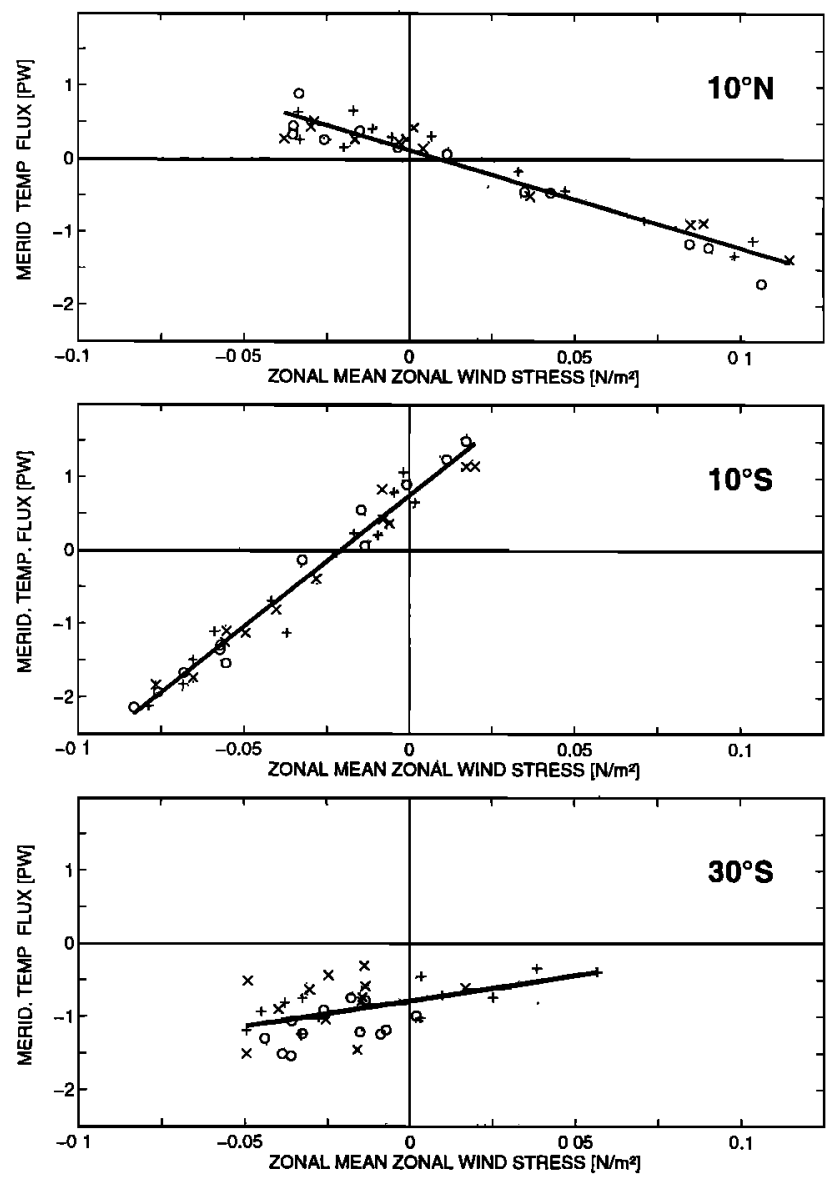

Figure 5. Correlation of the zonal mean zonal wind stress component with the meridional temperature flux at $10^{\circ} \mathrm{N}$, $10^{\circ} \mathrm{S}$, and $30^{\circ} \mathrm{S}$. Each data point is the average value of 1 month, where crosses denote data of 1987, pluses denote data of 1988 and open circles denote data of 1989. The linear fit is drawn together with the standard deviation (dotted line). 
Table 1. Data Related to the Linear Regression Analysis

\begin{tabular}{rccccc}
\hline Latitude & $\bar{Q}_{\mathrm{o}}, \mathrm{PW}$ & $a, \mathrm{PW}$ & $b, \mathrm{PW} / \mathrm{N} \mathrm{m}^{-2}$ & $r$ & $\sigma, \mathrm{PW}$ \\
\hline $20^{\circ} \mathrm{N}$ & -0.03 & 0.03 & -4.48 & -0.89 & 0.04 \\
$15^{\circ} \mathrm{N}$ & -0.09 & 0.03 & -7.54 & -0.91 & 0.14 \\
$10^{\circ} \mathrm{N}$ & -0.13 & 0.12 & -13.32 & -0.96 & 0.19 \\
$5^{\circ} \mathrm{N}$ & -0.12 & 0.25 & -27.91 & -0.90 & 0.41 \\
$\mathrm{EQU}$ & -0.18 & $\cdots$ & $\ldots$ & 0.88 & 0.52 \\
$5^{\circ} \mathrm{S}$ & -0.31 & 0.30 & 62.98 & 0.98 & 0.20 \\
$10^{\circ} \mathrm{S}$ & -0.43 & 0.75 & 35.86 & 0.96 & 0.31 \\
$15^{\circ} \mathrm{S}$ & -1.14 & 0.90 & 40.56 & 0.91 & 0.29 \\
$20^{\circ} \mathrm{S}$ & -1.07 & 0.85 & 38.65 & 0.66 & 0.31 \\
$25^{\circ} \mathrm{S}$ & -0.93 & -0.03 & 19.19 & 0.50 & 0.30 \\
$30^{\circ} \mathrm{S}$ & -0.91 & -0.79 & 7.01 & 0.69 & 0.22 \\
$35^{\circ} \mathrm{S}$ & -0.96 & -1.13 & 5.28 & & \\
\hline
\end{tabular}

Annual mean oceanic meridional temperature flux of the years $1987-1989, \bar{Q}_{0}$; the coefficients of the linear fit $a+b \tau^{(x)}=\tilde{Q}_{\mathrm{o}}$; the correlation coefficient of the meridional temperature flux and the zonal mean of the zonal wind stress component, $r$; the standard deviation of the monthly mean meridional temperature fluxes from the fitted line, $\sigma . \mathrm{EQU}$, equator.

there was an anomalous zonal wind stress to the east in the boreal summer of 1988. This can be seen in the bottom panel of Figure 5, where a few plus symbols representing months of boreal summer 1988 indicate positive zonal wind stress, while the majority of symbols from other years is clustered at negative zonal wind stress values, indicating that zonal wind stresses are typically directed to the west at $30^{\circ} \mathrm{S}$.

The results of this linear regression analysis are summarized in Table 1 . North of $20^{\circ} \mathrm{S}$ the linear relationship of the model's meridional temperature flux and the zonal mean of the zonal wind stress component is striking. This relationship can be seen from the correlation coefficients, which exceed 0.87 for these latitudes. In agreement with the Ekman theory for a wind-driven surface layer the absolute value of the gradient of the fitted line increases toward the equator. This increase results from the decrease of the Coriolis parameter to low latitudes, leading to an increased sensitivity of the meridional Ekman transport $-\tau^{(x)} / f$ and the associated temperature flux to the zonal wind stress near the equator. The changing sign of the gradient of the linear fit is related to the changing sign of the Coriolis parameter at the equator. The standard deviation increases significantly for sections in the vicinity of the equator. This increase indicates the different dynamics of the equatorial plane, which is predominated by the existence of equatorially trapped waves. Thus the temperature flux variations of the northern Indian Ocean are steered to a great extent by the Ekman transport in the surface layer. As a practical consequence the monthly mean meridional temperature flux, and north of $5^{\circ} \mathrm{S}$ the heat flux, can be determined from the zonal mean of the zonal wind stress component together with the coefficients of the linear fit, assuming that the circulation of the real ocean is represented in a reasonable way by the model. North of $20^{\circ} \mathrm{S}$ and away from the equator this method might lead to monthly mean temperature flux estimates with a standard error of less than $0.3 \mathrm{PW}$.
To determine how much of the meridional temperature flux is due to the wind stress, it is necessary to think about how the deep ocean is influenced by the wind. The answer to this question is far from trivial and has been discussed in context with meridional heat fluxes by Böning and Herrmann [1994], for instance. A widely used method is to assume an Ekman transport in the surface layer that is connected to a compensating barotropic current with the section mean temperature. Although there is no evidence that the wind-driven circulation behaves in that way in the Indian Ocean, the calculation has been carried out in this way in

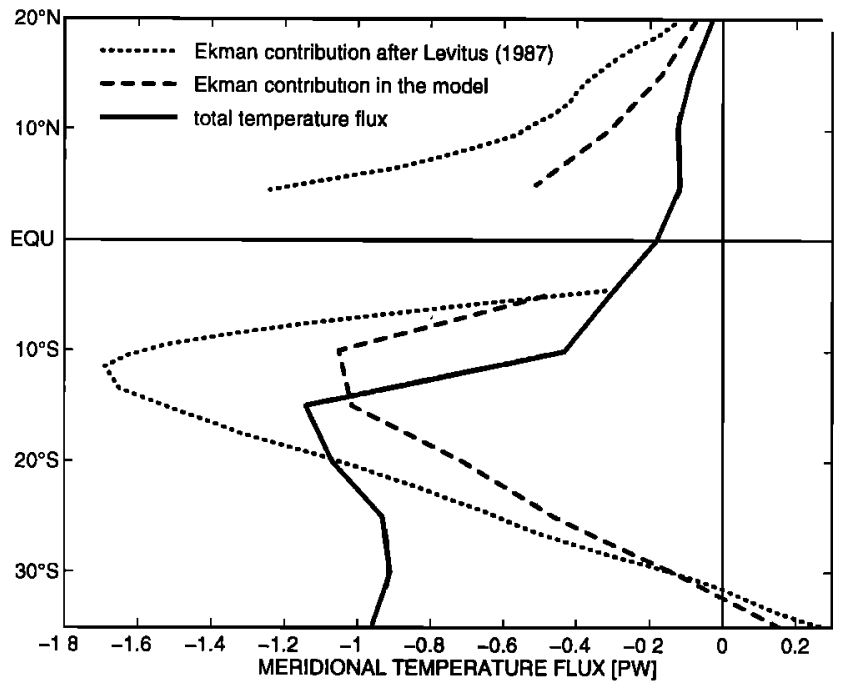

Figure 6. Annual mean meridional temperature transport of the model and its Ekman contribution. The latter is based on the Ekman transport at the temperature of the surface layer and a compensating barotropic current at section mean temperature. For comparison the values of Levitus [1987] are shown, which are based upon the same principle, using the wind stress climatology of Hellerman and Rosenstein [1983] and hydrographic data of Levitus [1982]. 
order to compare the estimates with those of Levitus [1987] (Figure 6). Levitus [1987] has used the wind stress climatology of Hellerman and Rosenstein [1983] and the temperature data of Levitus [1982] for the same kind of calculation. These two calculations show a similar meridional structure. The maximum of southward heat flux due to the Ekman contribution appears between $10^{\circ}$ and $15^{\circ} \mathrm{S}$, where, rarely influenced by the changing monsoon winds of the northern Indian Ocean, steady, rather strong trade winds from the southeast prevail. The maximum of the total meridional heat flux at $15^{\circ} \mathrm{S}$ is slightly shifted to the south against the maximum of the Ekman contribution at about $12^{\circ} \mathrm{S}$. South of the equator the model's Ekman contribution amounts to two thirds of the values derived from the climatology; north of the equator it is only about one half. This is a consequence of the less intense winds in the 3-year mean of the ECMWF analysis compared with climatological values of Hellerman and Rosenstein [1983], while the ocean temperatures are almost the same in both studies.

Figure 7 shows the annual mean stream function of the meridional volume flux for the years 1987-1989. North of $10^{\circ} \mathrm{S}$ the stream function is exact; south of this latitude it is an approximation. There is only little lateral inflow from the Sunda Straits with a mean value of $-0.72 \mathrm{~Sv}$ at $6^{\circ} \mathrm{S}$. The model shows a structure of three vertical cells in its southern hemisphere. One cell is located within the thermocline and transports $-13 \mathrm{~Sv}$. Another cell circulates in the deep ocean at $-3 \mathrm{~Sv}$. The negative sign denotes counterclockwise rotation; i.e., the inflow of these cells is below the outflow to the south, and hence both cells serve to transport heat to the south. A third cell appears at intermediate depths with circulation in the opposite sense. It is supplied by subduction from the subtropics during austral winter (see below).

Beside these three cells reaching farther into the southern Indian Ocean there is another shallow cell at the equa-

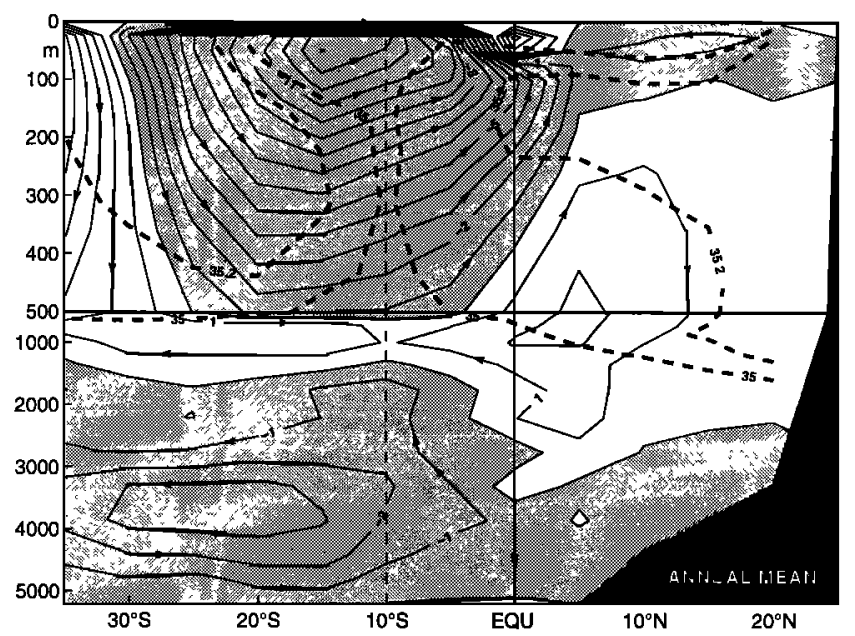

Figure 7. Annual mean stream function of meridional volume transport (1987-1989) for the Indian Ocean. The lateral inflow from the Pacific has been subtracted south of $10^{\circ} \mathrm{S}$ (see text). The dashed lines represent the annual mean of the zonal mean salinity distribution. Only the 35 and 35.2 psu contour lines have been drawn.
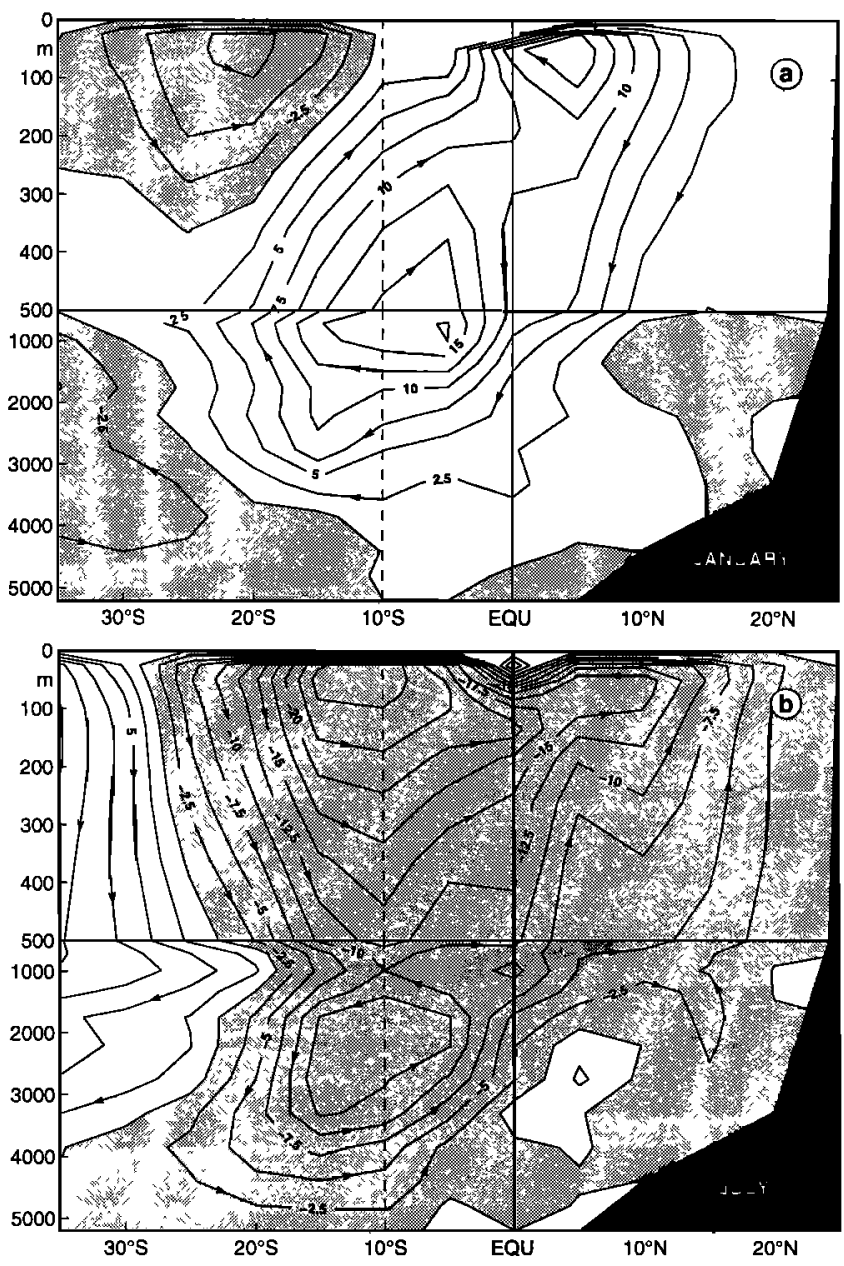

Figure 8. Same as in Figure 7 but for the monthly mean stream function (a) during the NE monsoon (January) and (b) during the SW monsoon (July). The contour interval is $2.5 \mathrm{~Sv}$.

tor of $+4 \mathrm{~Sv}$. This equatorial roll is symmetrically confined to the equator within less than $5^{\circ}$ of latitude and extends over the upper $50 \mathrm{~m}$ of the water column. A similar equatorial roll of $+7 \mathrm{~Sv}$ and $75 \mathrm{~m}$ depth has been found by Wacongne and Pacanowski [1996] in their evaluation of the GFDL Indian Ocean model. Figures of the stream function for single months (not shown) exhibit the beginning of this roll in April; the roll is fully developed in August with $+10 \mathrm{~Sv}$ when the southwest monsoon blows from the south over the western equatorial Indian Ocean; in October it vanishes. It is worth noting that Kindle and Thompson [1989] in a one-active-layer reduced-gravity model of the Indian Ocean found maximum meridional surface velocities on the equator in the western Indian Ocean in the second half of the year, which they attributed to Yanai waves.

Single months of the stream function differ substantially from the annual mean scheme as a result of changing monsoon winds. As an example the stream functions for January and July are shown in Figures $8 \mathrm{a}$ and $8 \mathrm{~b}$. These two figures represent the oceanic circulation of a fully developed NE and SW monsoon, respectively. The changing monsoon 
winds lead to a change of the circulation in the whole water column.

In January a vertical cell of $+17.5 \mathrm{~Sv}$ centered at about $800 \mathrm{~m}$ depth transports warm water into the northern Indian Ocean compensated by a cold southward flow in layers below up to the bottom. A total of $5 \mathrm{~Sv}$ of deep and bottom water enters the Indian Ocean at $35^{\circ} \mathrm{S}$ below $2000 \mathrm{~m}$ depth.

The circulation in July is almost reversed in comparison with that in January. Centered at $10^{\circ} \mathrm{S}$ a total of $-25 \mathrm{~Sv}$ is transported by two cells, leading to a heat export to the south. The exchange is enhanced in comparison with January, because wind speeds of the SW monsoon exceed those of the NE monsoon on average. Besides a small southward flow of $-5 \mathrm{~Sv}$ in $1000-2000 \mathrm{~m}$ the major transport to the south of $-20 \mathrm{~Sv}$ occurs in the upper $50 \mathrm{~m}$. The latter is originated by the strong southward Ekman transport, which is rather uniformly distributed over the entire interior ocean away from the African coast at these latitudes. The northward transport into the northern Indian Ocean occurs at $10^{\circ} \mathrm{S}$ in equal partitions of $+12.5 \mathrm{~Sv}$ between $50-1000 \mathrm{~m}$ and $2000-4500 \mathrm{~m}$. During the SW monsoon the southward transport of the surface layer dives down the equatorial roll at the equator. Such a large-scale cell structure can be obtained only for individual months of a fully developed monsoon current circulation. At other times (not shown) there were additional smallerscale cell structures with a different sense of rotation. South of $25^{\circ} \mathrm{S}$ a substantial amount of subtropical water is subducted into intermediate layers. This results in a tongue of saline water spreading from the surface around $30^{\circ} \mathrm{S}$ down to $200-500 \mathrm{~m}$ depth at $10^{\circ} \mathrm{S}$ (Figure 7). However, streamlines must not be interpreted as pathways of single water parcels, because they only describe the sum of basin-wide integrated motion.

Comparing the meridional stream functions north of $10^{\circ} \mathrm{S}$ with those from Wacongne and Pacanowski [1996], we find no significant difference. The annual mean stream function, and hence the associated heat flux, are almost identical to this study (Figure 3). For individual months the stream functions differ in the strength of their cells up to $10 \mathrm{~Sv}$, but the structure of the cells itself is very similar (not shown). In another regional Indian Ocean model by Lee and Marotzke [1997], in which the model was fitted to observations by the adjoint method, the shallow overturning cell north of the equator is much stronger in all of their different model runs than the une found in this study. They were also able to force a deep inflow at their southern boundary at $32^{\circ} \mathrm{S}$ that is much enhanced against the low inflow seen in Figure 7. But it required deep eastward flow into the buffer zone located at the entrance of the Indonesian passage with an associated westward outflow in the upper ocean. In the annual mean stream function (Figure 7) an overturning cell of approximately $15 \mathrm{~Sv}$ with a center of rotation in $50 \mathrm{~m}$ depth is present in all three models [this study; Wacongne and Pacanowski, 1996; Lee and Marotzke, 1997] in the upper $500 \mathrm{~m}$ at $15^{\circ} \mathrm{S}$. This and the aforementioned equatorial roll seem to be robust features of these models, which are all based upon the model principles described by Bryan [1969] and $\operatorname{Cox}$ [1975].

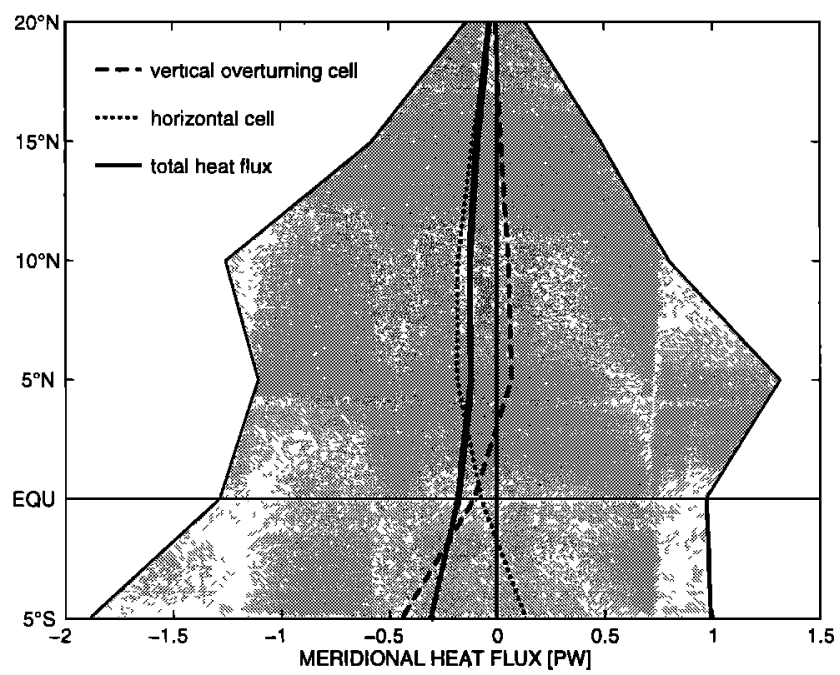

Figure 9. Annual mean contribution of the vertical overturning cell and of the horizontal cell to the total annual mean meridional heat flux. The shaded area covers the range of single-month values of the contribution of the vertical overturning cell for the period 1987-1989. Maximum negative values are reached during SW monsoon, and maximum positive values are reached during NE monsoon.

To get an idea of how much of the meridional heat flux is due to vertical overturning, the total heat flux has been divided into two components: a horizontal component with no net zonal mean volume flux at any depth and a vertical overturning cell, which is the residual of total minus horizontal cell motion. The resulting heat flux for each component together with the total heat flux are shown in Figure 9. North of the equator the horizontal cell is the main contributor to the meridional heat flux. The vertical overturning cell has a weak transport to the north, which can be seen in the annual mean stream function (Figure 7) as a vertical cell at intermediate depth with clockwise rotation, i.e., a warm flow to the north above a colder outflow to the south. South of the equator this scheme changes, and the vertical overturning cell becomes the major contributor to the annual mean meridional heat flux, as is also apparent from the annual mean meridional stream function. At $5^{\circ} \mathrm{S}$ the vertical cell transports $-0.44 \mathrm{PW}$ to the south, 4 times as much as the horizontal cell transports to the north. It is an interesting feature that the annual mean contribution of the vertical cell dominates only south of the equator, although its seasonal range of variation (shaded area in Figure 9) is an order of magnitude higher than its annual mean value. During the SW monsoon the vertical cell's southward heat transport is increased in comparison with the annual mean value, while the opposite is true during the NE monsoon. The seasonal variability of the horizontal cell is very small; hence the annual variability is an effect of the reversing vertical overturning cell alone. But the transports of both monsoon seasons counteract each other north of the equator, yielding a negligible annual mean transport of the overturning cell there. A dominant contribution of the vertical cell to the seasonal variance resembles the results of Wacongne and Pacanowski [1996]. 


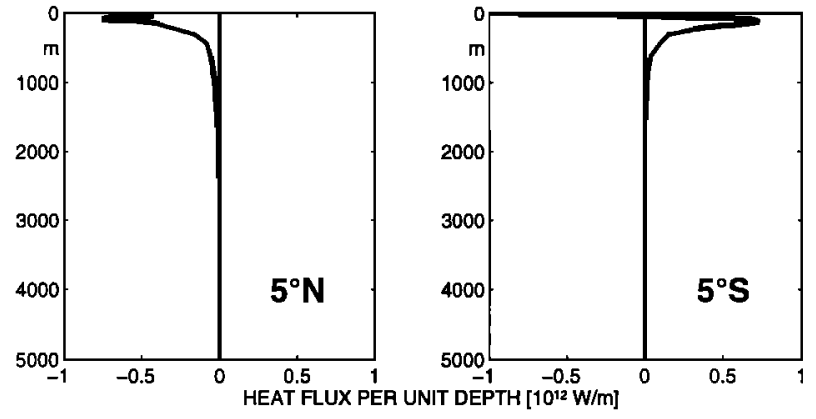

Figure 10. Annual mean heat flux per unit depth contributed by the horizontal cell at (left) $5^{\circ} \mathrm{N}$ and (right) $5^{\circ} \mathrm{S}$.

Dividing up the meridional heat flux in that way yields a function of heat flux per unit depth related to the horizontal cell (Figure 10). The vertical structure of this function exhibits a heat flux confined to the upper $500 \mathrm{~m}$. North of the equator it is southward at all depths. South of the equator there is a shallow southward heat flux in the surface layer $(0-25 \mathrm{~m})$ with an underlying northward heat flux, which is maximal at about $160 \mathrm{~m}$. The contribution of the overturning cell can be integrated over ranges of zero volume flux to obtain the energy transported within single overturning cells. At $5^{\circ} \mathrm{S}$ the shallow cell $(0-500 \mathrm{~m})$ transports $-0.46 \mathrm{PW}$, and another deep cell $(1500-4800 \mathrm{~m})$ transports $-0.01 \mathrm{PW}$ to the south. The overturning cell transports $0.03 \mathrm{PW}$ to the north. In summary, the upper vertical cell $(0-500 \mathrm{~m})$ is the major contributor to the annual mean meridional heat flux across $5^{\circ} \mathrm{S}$, whereas the horizontal cell confined to the upper $500 \mathrm{~m}$ dominates north of the equator.

\section{Influence of the Pacific-Indian Ocean Throughflow}

Numerous attempts with different methods have been made to determine the transport from the Pacific into the Indian Ocean through the Indonesian passage. Results range from negligible transport to -20 Sv [e.g., Godfrey, 1996]. Some authors [e.g., Hsiung, 1985; Hastenrath and Greischar, 1993; Trenberth and Solomon, 1994] based their heat flux integrations on a zero throughflow, which makes them difficult to compare with these model results south of $5^{\circ} \mathrm{S}$. In some analyses of oceanic observations the Pacific-Indian Ocean throughflow appears to be an important part of the global conveyor belt, especially as part of the warm water route [Gordon, 1986; Schmitz, 1995]. On the other hand, Macdonald [1993] showed in an inverse calculation involving zonal sections of all three southern oceans that the Pacific and the Indian Ocean heat transports were only weakly affected by modifying the throughflow between 0 and $20 \mathrm{~Sv}$.

The time series of the volume flux related to the model's Pacific-Indian Ocean throughflow across the section at $120^{\circ} \mathrm{E}$ for the period 1987-1989 can be seen in Figure 11. If we assume that it qualitatively represents the real conditions, it becomes evident that estimates of the amount of the throughflow from single observations must suffer from large annual and interannual variability. In the model, monthly mean values range from $+4 \mathrm{~Sv}$ (eastward) to $-19 \mathrm{~Sv}$ (westward) during the period 1987-1989. The mean value is $-8.8 \pm 5.1 \mathrm{~Sv}$, which is half the $-17.7 \mathrm{~Sv}$ in the preceding model version with $1 / 2^{\circ}$ grid spacing [McCann et al., 1994]. Darkly shaded areas indicate months with negative anomalies of the Pacific-Indian Ocean throughflow, i.e., a strong inflow from the Pacific in comparison with the mean annual cycle of the period 1987-1989. Lightly shaded areas indicate an anomalously weak inflow from the Pacific. In 1987 the inflow is anomalously weak, while a comparably strong inflow appears in the second half of the following year 1988 and in the beginning of 1989 . The same feature is shown by the calculation of the running mean of 12 months, which yields $-6 \mathrm{~Sv}$ in the middle of 1987 . The running mean takes an almost constant value of $-10 \mathrm{~Sv}$ from the middle of 1988 on.

Figure 12 shows the mean annual cycle of the PacificIndian Ocean throughflow together with the minima and maxima of individual months. The annual cycle is dominated by the annual harmonic. The inflow from the Pacific has its maximum in August with $-15 \mathrm{~Sv}$ and is minimal in boreal winter with about $-4 \mathrm{~Sv}$ in the mean.

The monthly transport values exhibit a strong interannual variability, especially in boreal summer and in January/February (Figure 12), when minimum and maximum values of a single month differ up to $12 \mathrm{~Sv}$. The interannual variability is less pronounced in March-June and in November. That might be the most opportune time to compare observations with results from seasonally varying models. Meyers [1996] found minimum interannual variability

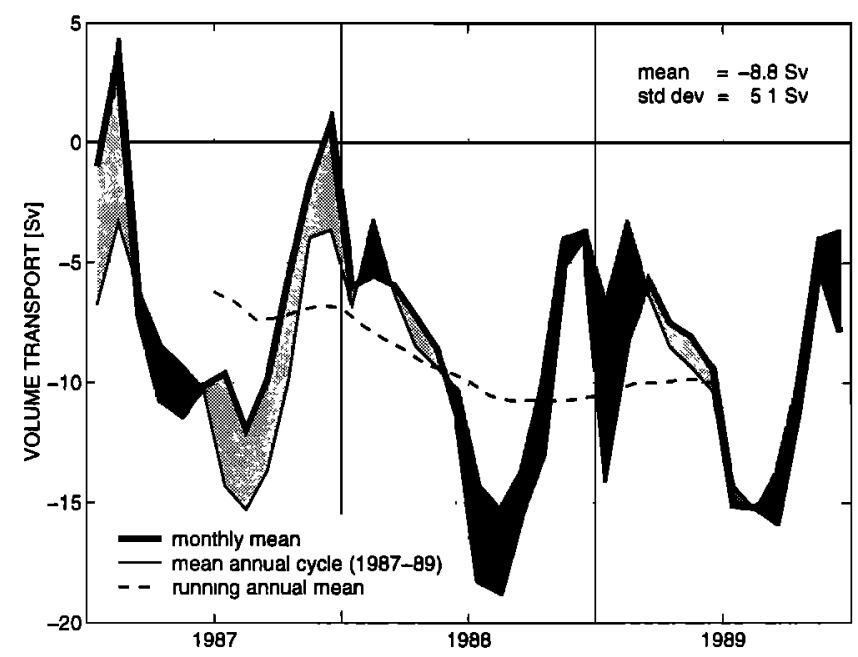

Figure 11. The heavy line represents the time series of the volume transport of the Pacific-Indian Ocean throughflow across the section at $120^{\circ} \mathrm{E}$ between Australia and the Indonesian Archipelago for the years 1987-1989. The thin line describes the mean annual cycle for this period of 3 years. A running mean over 12 months is shown as dashed line. Negative values indicate an inflow from the Pacific into the Indian Ocean. Darkly shaded areas show negative anomalies of the throughflow, i.e., a strong inflow from the Pacific compared with the mean value for this month. Lightly shaded areas indicate an anomalous weak inflow from the Pacific. 


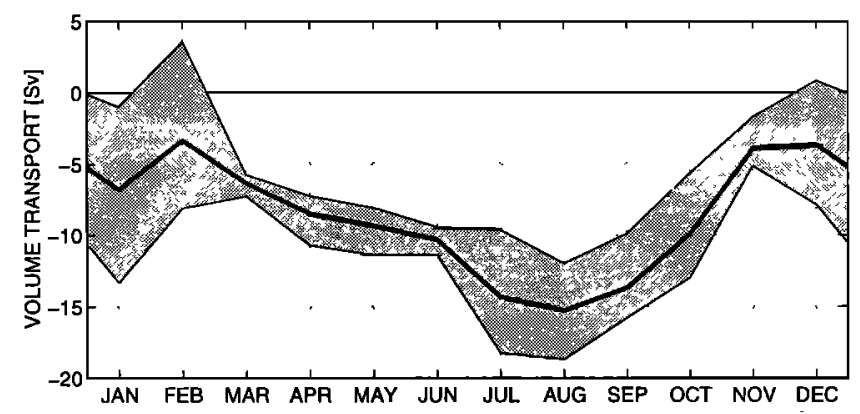

Figure 12. Mean annual cycle (heavy line) and range of the Pacific-Indian Ocean throughflow across the section at $120^{\circ} \mathrm{E}$ between Australia and the Indonesian Archipelago for the years 1987-1989. Negative values are related to inflow from the Pacific into the Indian Ocean.

of the geostrophic throughflow in the upper $400 \mathrm{~m}$ in May in a study analyzing 11 years of expendable bathythermograph (XBT) observations between Australia and Java at roughly $110^{\circ} \mathrm{E}$.

The influence of the Pacific-Indian Ocean throughflow on the heat budget of the Indian Ocean can be seen in Figure 13, which presents the mean temperature flux across the marked sections. There is southward meridional temperature flux in the whole Indian Ocean. At $10^{\circ} \mathrm{N}, 80 \%$ of the mean meridional heat flux occurs in the Arabian Sea, whereas the Bay of Bengal remains of minor importance while contributing the rest (not shown). The inflow from the Pacific accounts for $-0.82 \mathrm{PW}$ across the section at $120^{\circ} \mathrm{E}$ and, in addition, -0.08 PW through the Sunda Strait between Java and Sumatra. The preceding model version with $1 / 2^{\circ}$ grid spacing and monthly mean climatological wind stress had a temperature flux of $-1.08 \mathrm{PW}$ [McCann et al., 1994]. The model of the Indian Ocean by Hirst and Godfrey [1993] transports $-0.63 \mathrm{PW}$ from the Pacific into the Indian Ocean while ap-

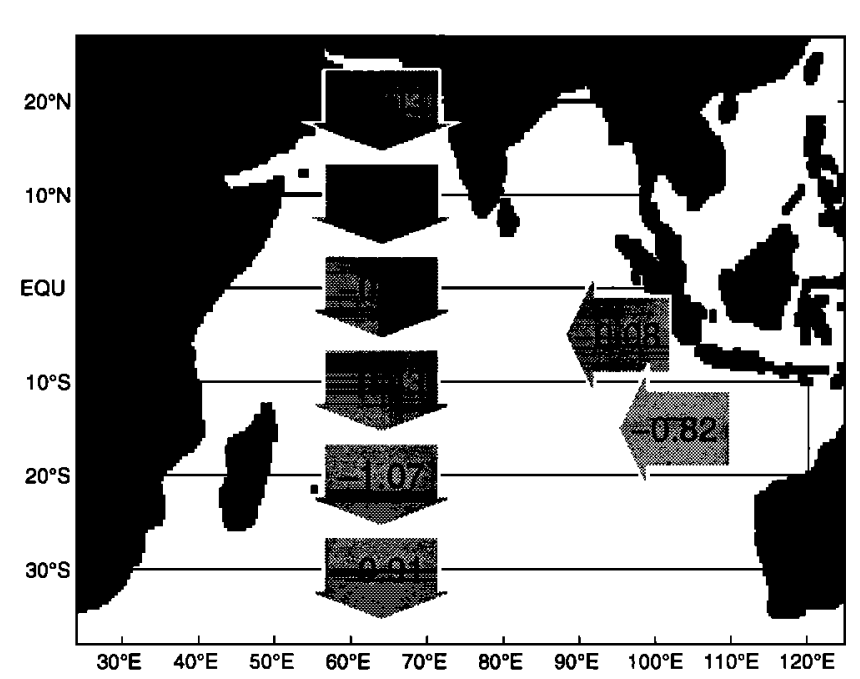

Figure 13. Mean temperature flux (1987-1989) in the Indian Ocean in PW. The arrows at the right-hand side describe the transports from the Pacific across the section at $120^{\circ} \mathrm{E}$ and through the Sunda Strait between Java and Sumatra (at $\left.105^{\circ} \mathrm{E}, 6^{\circ} \mathrm{S}\right)$. plying constant mean winds. About two thirds of the intensification of the meridional temperature flux between $10^{\circ}$ and $20^{\circ} \mathrm{S}$ is associated with the lateral inflow from the Pacific. Only one third of the model's temperature flux south of the Pacific-Indian Ocean throughflow has its origin in the accumulation of solar heat in the northern Indian Ocean (Figure 13).

The Pacific-Indian Ocean throughflow and its associated temperature flux are highly correlated to the local zonal wind stress. Figure 14 shows the correlation coefficients calculated from the time series of the volume transport across the section along $120^{\circ} \mathrm{E}$ and the zonal component of the local wind stress in the Indian Ocean and the throughflow region. The highest correlation coefficients of more than 0.75 are found south of Java near the transport section along $120^{\circ} \mathrm{E}$. The 95\% significance level, i.e., the correlation coefficient at which the probability that the correlation is different from zero has a chance of $95 \%$, is 0.5 with the assumption of 10 degrees of freedom for the time series, which covers a period of 3 years. In the latitude range $5^{\circ}-20^{\circ} \mathrm{S}$ correlation coefficients of more than 0.5 are present across almost the whole basin east of $50^{\circ} \mathrm{E}$. The high correlation between the zonal mean of the zonal wind stress component and the meridional temperature flux found in the latitude range $10^{\circ}-20^{\circ} \mathrm{S}(\mathrm{Ta}-$ ble 1) together with the high correlation between the zonal wind stress and the Pacific-Indian Ocean throughflow in a large area of that latitude range (Figure 14) explains why a large part of the meridional temperature flux is controlled by the zonal wind stress at those latitudes. The correlation arises from the near-synchronous annual cycle of the local wind and the throughflow. Comparing the anomalies from the annual cycle of both quantities does not yield any significant correlation except south of Java at $120^{\circ} \mathrm{E}$ (not shown).

Thus the principal role of the Indian Ocean in this model implementation is the transport of heat from the Pacific

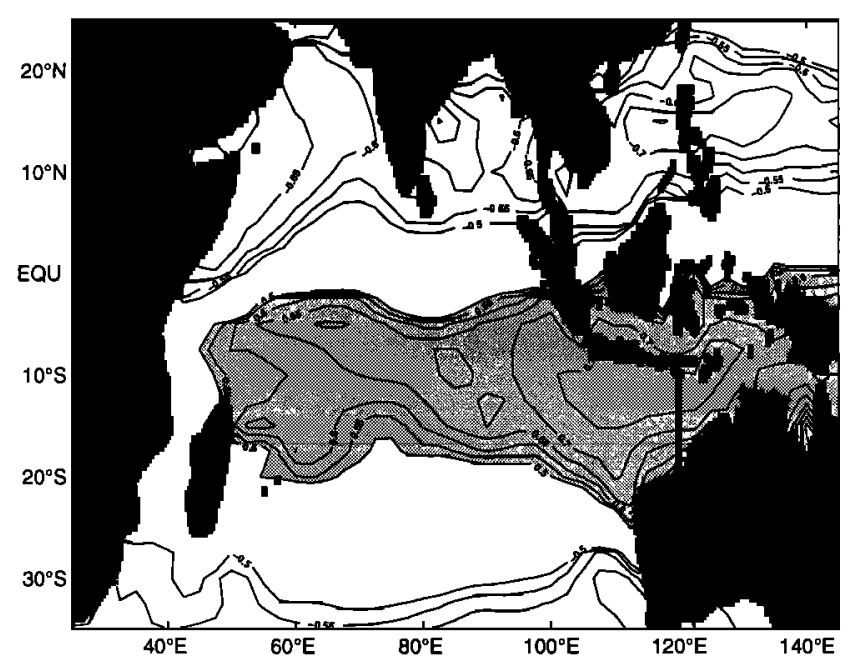

Figure 14. Correlation coefficients calculated between the time series of the volume flux through the section along $120^{\circ} \mathrm{E}$ and the zonal component of the local wind stress. Contour lines for correlation coefficients less than the $95 \%$ significance level of 0.5 have been omitted. The contour interval is 0.05 . 
through the Indian Ocean basin to the south, rather than the distribution of heat accumulated in the northern part from mainly solar radiation.

\section{Summary and Discussion}

A global eddy-resolving ocean model has been used to study advective temperature and heat fluxes in the Indian Ocean on the basis of monthly mean properties. The mean meridional heat flux in the northern Indian Ocean of the model is weak in comparison with the air-sea flux estimates of Hsiung [1985]. However, more recent publications [Hastenrath and Greischar, 1993; Trenberth and Solomon, 1994] show southward heat fluxes that are less intense than the earlier estimates of Hsiung [1985]. The weak heat flux in this model resembles a well-known phenomenon of today's high-resolution ocean models (for example, the Atlantic Ocean models described by Holland and Bryan [1994]; Böning et al. [1991]; Sarmiento [1986]) and is present in the preceding model version with $1 / 2^{\circ}$ grid spacing as well $[M c$ Cann et al., 1994]. In the former, too low a fraction of cold overflow North Atlantic Deep Water (NADW) was responsible; in the latter an unsatisfactory production of Antarctic Bottom Water (AABW) and Antarctic Intermediate Water (AAIW) was found to be the reason.

The annual cycle of the meridional heat flux in the northern Indian Ocean is in reasonable agreement with meridional heat transports derived from climatological air-sea fluxes and heat storage changes [Hsiung et al., 1989]. Increasing differences arise at southern latitudes.

North of $20^{\circ} \mathrm{S}$ a surprisingly strong correlation was found between the zonal mean of the zonal wind stress component and the meridional heat/temperature flux variability across individual latitudes. From the point of view of this work one might suggest that the strong correlation between the zonal wind stress and the meridional temperature flux, in conjunction with ECMWF wind stresses used in the model that are weak in comparison with those of Hellerman and Rosenstein [1983], lead to a weak meridional temperature flux in the model. Given the strong correlation, it is very likely that driving the model with a stronger wind product, for instance, the wind climatology of Hellerman and Rosenstein [1983], would produce a stronger southward heat flux. Lee and Marotzke [1997] investigated an Indian Ocean GCM fitted to hydrographic data, using its adjoint. It was driven by the annual mean wind fields of Hellerman and Rosenstein [1983] and exhibits cross-equatorial heat fluxes twice as high as those in this study due to a much stronger shallow overturning cell in the northern Indian Ocean. On the other hand, several numerical models exhibit a weak meridional temperature flux despite their different wind forcing [e.g., Wacongne and Pacanowski, 1996]. In the end it remains unresolved which of the different wind products is more realistic.

Another reason for a weak meridional heat flux might be given by an insufficient deep circulation. The relaxation to climatology that took place at depths below $700 \mathrm{~m}$ in the preceding 33 years of the simulation has been omitted in this

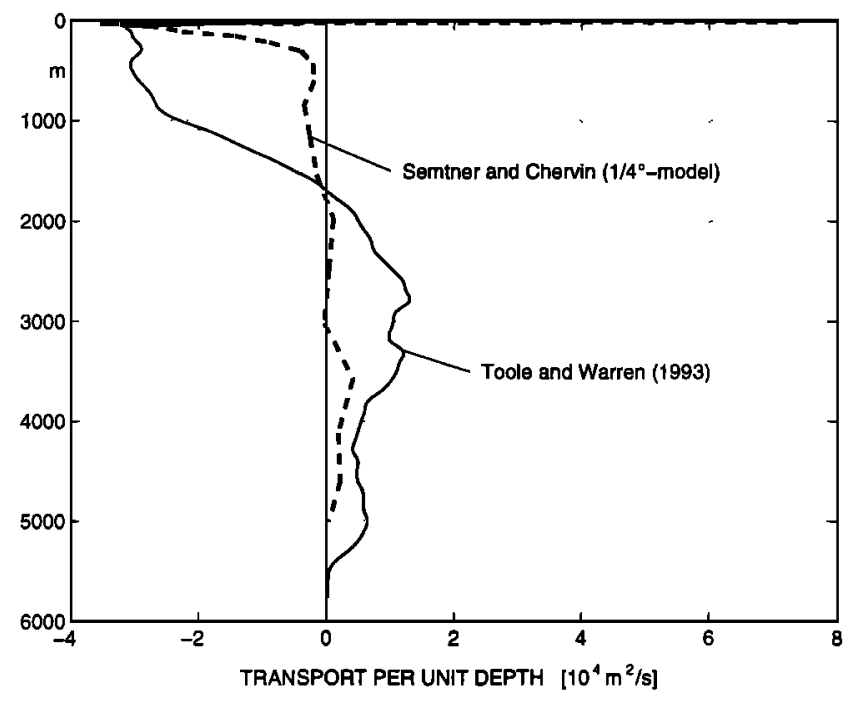

Figure 15. Transport per unit depth for NovemberDecember 1987 in the model along $35^{\circ} \mathrm{S}$ and from a transoceanic hydrographic section roughly along $32^{\circ} \mathrm{S}$ after Toole and Warren [1993].

model run. However, 5 years of integration without this deep forcing is a very short period for establishing a new equilibrium in the deep ocean. Therefore how the deep circulation evolves further remains an open and interesting question to more sophisticated model versions under way.

Toole and Warren [1993] report on a transoceanic hydrographic section roughly along $32^{\circ} \mathrm{S}$ in November-December 1987. In Figure 15 the transport per unit depth of this cruise is compared with the section along $35^{\circ} \mathrm{S}$ of the Semtner and Chervin $1 / 4^{\circ}$ model for the same period. The total transport of $-7 \mathrm{~Sv}$ inferred from the hydrographic survey in November-December does not resemble the model's negligible transport at that time of the year. The resulting zero level of the overturning cell of Toole and Warren [1993] is in agreement with the model's meridional current structure that shows a transport close to zero at $2000 \mathrm{~m}$ depth. Northward transports below $2000 \mathrm{~m}$ are much enhanced in the observations compared with the model. In the upper ocean the southward flow is confined to the upper $250 \mathrm{~m}$, while the observations exhibit strong southward flow even to depths up to $1500 \mathrm{~m}$. The northward Ekman transport across $35^{\circ} \mathrm{S}$ is $1.7 \mathrm{~Sv}$ in the model and equals approximately the estimate of $1.6 \mathrm{~Sv}$ given by Toole and Warren [1993] for the $32^{\circ} \mathrm{S} \mathrm{sec}-$ tion. As a consequence of the stronger vertical overturning the observations show a much enhanced temperature flux of $-1.67 \mathrm{PW}$ in November-December 1987 in comparison with the mean temperature flux of $-0.68 \mathrm{PW}$ in the model for the same 2 months. However, a recent reevaluation of the $32^{\circ} \mathrm{S}$ data by Robbins and Toole [1997] concludes that the strong meridional overturning of $-27 \mathrm{~Sv}$ deduced by Toole and Warren [1993] is not in agreement with the silica budget. Closing this budget for the Indian Ocean north of $32^{\circ} \mathrm{S}$ would reduce the overturning rate to about half this amount.

As we already mentioned above, the vertical overturning in this model is comparably weak north of the equator; the 
horizontal gyre circulation confined to the upper $500 \mathrm{~m}$ is the main contributor to the small meridional heat flux to the south. By contrast, a vertical overturning cell confined to the upper $500 \mathrm{~m}$ dominates the meridional heat transport at $5^{\circ} \mathrm{S}$. The change of monsoon winds is manifested in a reversal of the direction of the vertical overturning circulation throughout the whole water column.

The model's mean Pacific-Indian Ocean throughflow across the section at $120^{\circ} \mathrm{E}$ amounts to $-8.8 \pm 5.1 \mathrm{~Sv}$ with a strong interannual variability in January/February and boreal summer of up to $12 \mathrm{~Sv}$. The throughflow is highly correlated to the local zonal wind stress south of Java. The total inflow from the Pacific to the Indian Ocean results in a mean temperature flux of $-0.9 \mathrm{PW}$. There is indication that the weak Pacific-Indian Ocean throughflow in 1987 is a consequence of the observed El Niño-Southern Oscillation (ENSO) event in 1986-1987. This leads to the suggestion that in the year after a moderate El Niño the annual mean throughflow is anomalously weak with $-6 \mathrm{~Sv}$, whereas the usual mean volume transport is $-10 \mathrm{~Sv}$ during the La Niña phase. Anderson and Carrington [1993] found anomalous equatorial currents in 1987 in their OGCM driven by United Kingdom Meteorological Office winds as well. But the short time series of only 3 years restricts the ability to analyze the influence of this phenomenon, which repeats about every $3-5$ years. Another explanation for the interannual change of the throughflow might be oscillations of the numerical model itself that appear at the beginning of the integration. Their occurrence follows from the adaption to a new statistical equilibrium, which has been necessary because of the changing dynamics of the model, namely, the change of wind forcing, resolution, and relaxation to climatology in the deep ocean.

This study has found that about two thirds of the temperature flux leaving the Indian Ocean to the south is fed by the inflow from the Pacific via the Indonesian passage. The values of the throughflow are within the range of observations. The dominance of the throughflow in setting the southern Indian Ocean heat export of this model is at variance with the inverse model analysis of Macdonald [1993], who found negligible influence of the throughflow on the Pacific and Indian Ocean meridional temperature flux. In the model the dominance of the temperature transport from the Pacific is due not to unrealistically high throughflow rates, but to the consequence of weak meridional heat fluxes out of the northern Indian Ocean. The latter reside at the low end of the published values. Climatologies show a wide range of values; therefore it remains uncertain whether the relatively weak sea surface fluxes of the model's northern Indian Ocean are reasonable or whether the simple parameterization scheme of relaxing to the sea surface temperatures of Levitus [1982] leads to an underestimation of the net heat input at the surface. The model does not exhibit a noticeable trend of systematic warming or cooling at the timescale investigated here.

The model's meridional temperature flux variability has a strong linear correlation with the variability of the zonal mean of the zonal wind stress component north of $20^{\circ} \mathrm{S}$. In the high-resolution Atlantic Community Modeling Effort model the findings of Böning and Herrmann [1994] for the annual cycle were similar. In this model the annual cycle of heat flux was dominantly due to the Ekman transport variation, while the horizontal gyre component of the heat flux did not contribute much. If this relationship can be verified in the real Indian Ocean, the opportunity arises to determine the meridional temperature flux variability from the zonal wind stress alone, a product of operational weather analysis. As long as there are no reliable observations on the meridional temperature flux in the Indian Ocean, one can only speculate about the validity of this correlation in the real ocean. Therefore it might be an objective to obtain reliable temperature flux estimates from observations in different months at various latitudes to prove the existence of such correlations and then, if these are successful, to gain credible coefficients that describe the linear relationship of the wind stress and the temperature flux. One step toward this goal is the basinwide hydrographic zonal sections, together with associated mooring and drifter deployments conducted by the World Ocean Circulation Experiment near $8^{\circ} \mathrm{N}, 8^{\circ} \mathrm{S}$, and $20^{\circ} \mathrm{S}$ in the year 1995 [U.S. World Ocean Circulation Experiment, 1992]. Unfortunately, these measurements do not cover the annual cycle along whole basin-wide sections.

Although the model's results resemble much of the observed phenomena qualitatively, as is shown by the proper behavior of the surface circulation (Figure 2) and by the annual cycle of the meridional heat flux in the northern Indian Ocean (Figure 4), uncertainties still remain. The latter statement is underlined by the fact that, for instance, the PacificIndian Ocean throughflow has been reduced by a factor of 2 as the model's grid spacing changed [McCann et al., 1994]. Recent efforts to apply more realistic surface fluxes than simple relaxation to climatology and use of high-frequency wind stresses instead of monthly mean values, however, may have the potential to yield more realistic quantities.

Acknowledgments. We would like to thank A. J. Semtner (Naval Postgraduate School, Monterey, California) for making the high-resolution data available to us. Comments of an anonymous referee have been very helpful and are greatly appreciated. This work was funded by the German Minister of Education, Science, Research and Technology (BMBF) as part of the German WOCE program under grant WOCE IV 03F0157A.

\section{References}

Anderson, D., and D. Carrington, Modeling interannual variability in the Indian Ocean using momentum fluxes from United Kingdom Meteorological Office and European Centre for MediumRange Weather Forecasts, J. Geophys. Res., 98(C7), 12,48312,499, 1993.

Bjerknes, V., J. Bjerknes, H. Solberg, and T. Bergeron, Physikalische Hydrodynamik: mit Anwendungen auf die dynamische Meteorologie, Springer Verlag, New York, 797 pp., 1933.

Böning, C. W., and P. Herrmann, Annual cycle of poleward transport in the ocean: Results from high-resolution modeling of the North and Equatorial Atlantic, J. Phys. Oceanogr., 24(1), 91107, 1994.

Böning, C. W., R. Döscher, and R. G. Budich, Seasonal transport variation in the western subtropical North Atlantic: Experiments with an eddy-resolving model, J. Phys. Oceanogr., 21(9), 1271$1289,1991$. 
Bryan, K., Measurements of meridional heat transport by ocean currents, J. Geophys. Res., 67(9), 3403-3414, 1962.

Bryan, K., A numerical model for the study of the world ocean, $J$. Comput. Phys. , 4, 347-376, 1969.

Bryan, K., and L. J. Lewis, A water mass model of the world ocean, J. Geophys. Res., 84(C5), 2503-2517, 1979.

Bryden, H. L., and M. M. Hall, Heat transport by currents across $25^{\circ} \mathrm{N}$ latitude in the Atlantic Ocean, Science, 207, 884-886, 1980.

Carissimo, B. C., A. H. Oort, and T. H. V. Haar, Estimating the meridional energy transport in the atmosphere and ocean, $J$. Phys. Oceanogr., 15(1), 82-91, 1985.

Covey, C., Global ocean circulation and equator-pole heat transport as a function of ocean GCM resolution, Clim. Dyn., 11, 425-437, 1995.

Cox, M. D., A baroclinic numerical model of the world ocean: Preliminary results, in Numerical Models of Ocean Circulation, pp. 107-118, Nat. Acad. of Sci., Washington, D. C., 1975.

Godfrey, J. S., The effect of the Indonesian throughflow on ocean circulation and heat exchange with the atmosphere: A review, $J$. Geophys. Res., 101(C5), 12,217-12,237, 1996.

Gordon, A. L., Interocean exchange of thermocline water, J. Geophys. Res., 91(C4), 5037-5046, 1986.

Hastenrath, S., and L. Greischar, The monsoonal heat budget of the hydrosphere-atmosphere system in the Indian Ocean sector, $J$. Geophys. Res., 98(C4), 6869-6881, 1993.

Hellerman, S., and M. Rosenstein, Normal monthly wind stress over the world ocean with error estimates, J. Phys. Oceanogr., 13(7), 1093-1104, 1983.

Hirst, A. C., and J. S. Godfrey, The role of Indonesian throughflow in a global ocean GCM, J. Phys. Oceanogr., 23(6), 1057-1086, 1993.

Holland, W. R., and F. O. Bryan, Sensitivity studies on the role of the ocean climate change, in Ocean Processes in Climate Dynamics: Global and Mediterranean Examples, edited by P. Malanotte-Rizzoli and A. R. Robinson, pp. 111-134, Kluwer Acad., Norwell, Mass., 1994.

Hsiung, J., Estimates of global oceanic meridional heat transport, J. Phys. Oceanogr, 15(11), 1405-1413, 1985.

Hsiung, J., R. E. Newell, and T. Houghtby, The annual cycle of oceanic heat storage and oceanic meridional heat transport, $Q . J$. R. Meteorol. Soc., 115(485), 1-28, 1989.

Kindle, J. C., and J. D. Thompson, The 26- and 50-day oscillations in the western Indian Ocean: Model results, J. Geophys. Res., 94(C4), 4721-4736, 1989.

Lee, T., and J. Marotzke, Inferring meridional mass and heat transports of the Indian Ocean by fitting a general circulation model to climatological data, J. Geophys. Res., 102(C5), 10,585-10,602, 1997.

Levitus, S., Climatological atlas of the world oceans, NOAA Prof. Pap. 13, 173 pp., 1982.

Levitus, S., Meridional Ekman heat fluxes for the world ocean and individual ocean basins, J. Phys. Oceanogr., I7(9), 1484-1492, 1987.
Macdonald, A. M., Property fluxes at $30^{\circ} \mathrm{S}$ and their implications for the Pacific-Indian throughflow and the global heat budget, $J$. Geophys. Res., 98(C4), 6851-6868, 1993.

McCann, M. P., A. J. Semtner, and R. M. Chervin, Transports and budgets of volume, heat, and salt from a global eddy-resolving ocean model, Clim. Dyn., I0, 59-80, 1994.

Meyers, G., Variation of the Indonesian throughflow and the El Niño-Southern Oscillation, J. Geophys. Res., 101(C5), 12,255$12,263,1996$.

Robbins, P. E., and J. M. Toole, The dissolved silica budget as a constraint on the meridional overturning circulation of the Indian Ocean, Deep Sea Res., Part 1, 44(5), 879-906, 1997.

Sarmiento, J. L., On the north and tropical Atlantic heat balance, $J$. Geophys. Res., 91 (C10), 11,677-11,689, 1986.

Schmitz, W. J., Jr., On the interbasin-scale thermohaline circulation, Rev. Geophys., 33(2), 151-173, 1995.

Schott, F., Monsoon response of the Somali Current and associated upwelling, Prog. Oceanogr., 12, 357-381, 1983.

Schott, F., J. Reppin, and J. Fischer, Currents and transports of the monsoon current south of Sri Lanka, J. Geophys. Res., 99(C12), 25,127-25,141, 1994.

Semtner, A. J., Jr., and R. M. Chervin, A simulation of the global ocean circulation with resolved eddies, J. Geophys. Res., 93(C12), 15,502-15,522, 1988.

Semtner, A. J., Jr., and R. M. Chervin, Ocean general circulation from a global eddy-resolving model, J. Geophys. Res., 97(C4), 5493-5550, 1992

Sverdrup, H. U., M. W. Johnson, and R. H. Fleming, The Oceans: Their Physics, Chemistry and General Biology, 1087 pp., Prentice-Hall, Englewood Cliffs, N. J., 1942.

Swallow, J. C., F. Schott, and M. Fieux, Structure and transport of the East African Coastal Current, J. Geophys. Res., 96(C12), 22,245-22,257, 1991.

Toole, J. M., and B. A. Warren, A hydrographic section across the subtropical South Indian Ocean, Deep Sea Res., Part I, 40(10), 1973-2019, 1993.

Trenberth, K. E., and A. Solomon, The global heat balance: Heat transports in the atmosphere and ocean, Clim. Dyn., 10, 107134, 1994

U. S. World Ocean Circulation Experiment, U. S. Contribution to WOCE Core Project 1: The Program Design for the Indian Ocean, U. S. WOCE Off., Texas A\&M Univ., College Station, 1992.

Wacongne, S., and R. Pacanowski, Seasonal heat transport in a primitive equations model of the tropical Indian Ocean, $J$. Phys. Oceanogr., 26(12), 2666-2699, 1996.

Wunsch, C., Determining the general circulation of the oceans : A preliminary discussion, Science, 196, 871-874, 1977.

U. Garternicht and F. Schott, Institut für Meereskunde an der Universität Kiel, Düsternbrooker Weg 20, D-24105 Kiel, Germany. (e-mail: ugarternicht@ifm.uni-kiel.de; fschott@ifm.uni-kiel.de)

(Received October 8, 1996; revised April 11, 1997; accepted May 29, 1997.) 